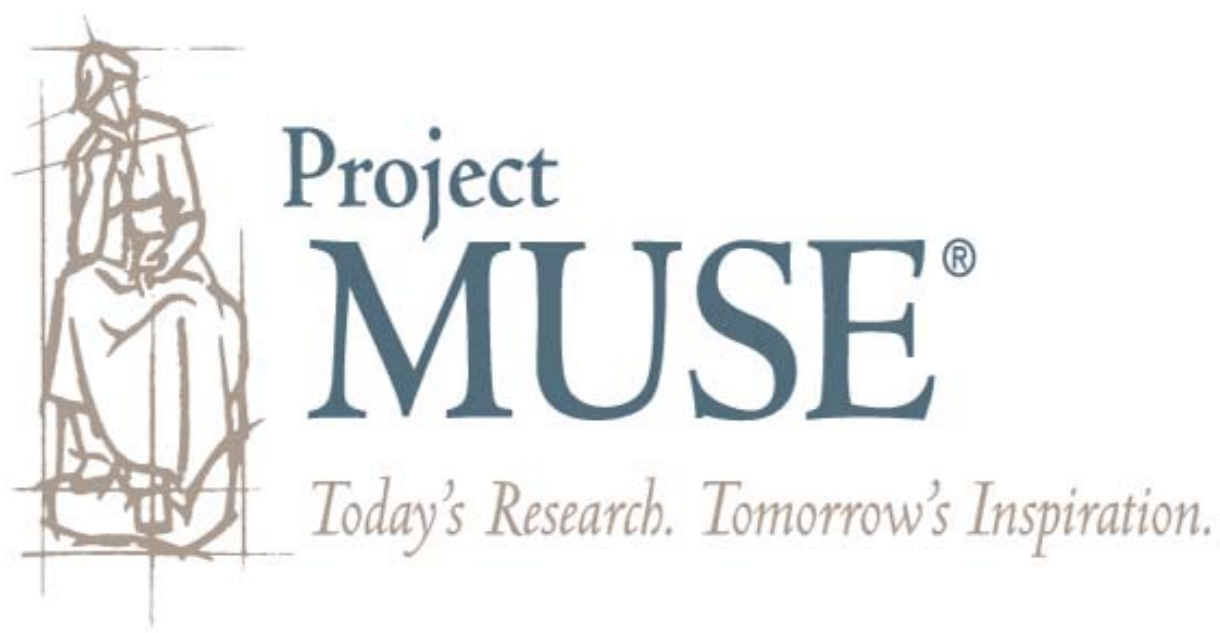




\title{
Constitutionalism, Legal Pluralism, and International Regimes
}

\author{
Alec Stone Sweet*
}

\begin{abstract}
The international legal order, although pluralist in structure, is in the process of being constitutionalized. This article supports this claim in several different ways. In the Part I, I argue that most accepted understandings of "constitution" would readily apply to at least some international regimes. In Part II, I discuss different notions of "constitutional pluralism," and demonstrate that legal pluralism is not necessarily antithetical to constitutionalism. In fact, one finds a great deal of constitutional pluralism within national legal orders in Europe. Part III puts forward an argument that the European Court of Justice, the European Court of Human Rights, and the Appellate Body of the World Trade Organization are constitutional jurisdictions. In the Conclusion, I respond what I take to be the most important objections to these claims.
\end{abstract}

\section{INTRODUCTION}

Does it make sense to deploy the concept of a "constitution" in analyses of public international law or specific international regimes? Does the turn to constitutionalism in international legal scholarship, however symbolically charged, reflect or portend some important qualitative change in how international law and governance is in fact organized? Does the fact of legal pluralism, or the absence of juridically natured systemic hierarchy in the international system, weaken or even exclude the claims of constitutionalists? As this issue shows, little agreement exists among scholars on how to answer such questions.

In this article, I develop and defend a constitutionalist position derived from

* Leitner Professor of Law, Politics, and International Studies, Yale Law School.

Indiana Journal of Global Legal Studies Vol. 16 \#2 (Summer 2009)

OIndiana University Maurer School of Law — Bloomington 
generic theoretical materials about the nature of constitutions and constitutionalism, as well as from the empirical domain of comparative constitutional law. For some readers, this strategy may seem ill-advised. Bardo Fassbender, for example, argues against constructing constitutional theories of international law with reference to comparative constitutional law, a domain that the theorist, it would seem, should ignore. ${ }^{1}$ Others, including scholars who contributed to this issue, approach international law and politics as if they were dissimilar to law and politics more generally, thus requiring the evolution of new concepts, rather than the application of existing ones. I respectfully disagree with these scholars and embrace the opposite approach.

The views presented here are partly based on arguments first developed in my

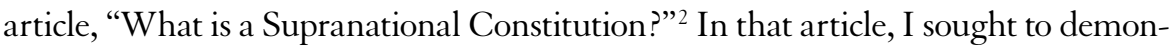
strate that the orthodox distinctions in mainstream international relations theory between constitutionally-organized states, on the one hand, and international regimes, on the other, were untenable. I developed a continuum on which to situate the structures of various regime forms. Simple power-based balance of power arrangements anchored one extreme, the European Union (EU) occupied the opposite extreme, and other regime forms, including the General Agreement on Tariffs and Trade (GATT) and the then-new World Trade Organization (WTO), occupied the middle ground. The continuum captures three dimensions: the extent of hierarchical primacy and entrenchment of the constituting norms; the degree of precision and formality of legal obligation; and the scope of independent, organizational capacity to monitor compliance with, and to enforce, obligations. ${ }^{3}$ In subsequent work, I developed a theory of how, and under what conditions, judicial power might emerge and institutionalize as a self-sustaining mechanism of governance and institutional change. ${ }^{4}$ I then used that theory to explain the judicialization and constitutionalization of various political systems, including supranational systems. ${ }^{5}$

1. Bardo Fassbender, "We the Peoples of the United Nations": Constituent Power and Constitutional Form in International Law, in The Paradox of Constitutionalism 269, 269 (Martin Loughlin \& Neil Walker eds., 2007).

2. See generally Alec Stone, What is a Supranational Constitution? An Essay in International Relations Theory, 56 Rev. Pol. 441 (1994).

3. This framework subsequently developed into the theoretical basis for The Institutionalization of Europe (Alec Stone Sweet et al. eds., 2001). See also Kenneth W. Abbott et al., The Concept of Legalization, 54 Int'L Org. 401, 401 (2000); Judith Goldstein et al., Introduction: Legalization and World Politics, 54 Int'L Org. 385, 387 (2000).

4. See generally Alec Stone Sweet, Judicialization and the Construction of Governance, 32 Comp. Pol. STud. 147 (1999).

5. See generally Alec Stone Sweet, The Judicial Construction of Europe (2004); Neil Fligstein \& Alec Stone Sweet, Constructing Polities and Markets: An Institutionalist Account of European 
In this article, I treat basic questions about the organization of legal norms and the defense of normative hierarchies as inherently constitutional questions. I do so by addressing three debates bearing on these matters. Part I addresses the first debate: defining and employing the concepts "constitution" and "constitutionalism.” I will argue that some basic understandings of these concepts comfortably make space for forms of international organization. Those who disagree must define these notions so as to exclude treaty-constituted forms while capturing the constitutional systems of most states developed over the past two centuries. The second debate, addressed in Part II, concerns the supposed dichotomy between "legal pluralist" and "constitutionalist" models of the international legal system. I demonstrate that this is a false dichotomy. Many national constitutional systems are, in fact, full of legal pluralism, with corresponding gaps in the authority of constitutional courts. Part III responds to the third debate: the extent to which the courts of some international treaty regimes operate as "constitutional courts." In each of these Parts, I reference three treaty-constituted systems that are arguably "constitutional" in some meaningful sense: the EU, ${ }^{6}$ the European Court of Human Rights (ECtHR), ${ }^{7}$ and the WTO. ${ }^{8}$

\section{I. "Constitutions" and "Constitutionalism"}

A lack of consensus exists in defining the concepts of "constitution" and "constitutionalism." My aim here is to survey various understandings of these terms in order to situate my claims in this article, not to fix any authoritative meanings.

Integration, 107 Aм. J. Soc. 1206 (2002) (showing that the growth of intra-European Commission (EC) trade and the "constitutionalization" of the EC legal system are causally interconnected); Alec Stone Sweet \& Thomas L. Brunell, Constructing a Supranational Constitution: Dispute Resolution and Governance in the European Community, 92 Am. Pol. Scr. Rev. 63 (1998).

6. See generally J.H.H. Weiler, The Constitution of Europe: "Do the New Clothes Have an Emperor” and Other Essays on European Integration (1999); G. Federico Mancini, The Making of a Constitution for Europe, 26 Common Mкт. L. Rev. 596 (1989); Eric Stein, Lawyers, Judges, and the Making of a Transnational Constitution, 75 Am. J. Int'L L. 1 (1981).

7. See also Steven Greer, The European Convention on Human Rights (2006) (discussing the "constitutionalization" of the European Convention on Human Rights and the "constitutional justice" dispensed by the European Court of Human Rights). See generally Evert Albert Alkema, The European Convention as a Constitution and Its Court as a Constitutional Court, in Protection des droits de L'homme: la perspective européenne 41 (Paul Mahoney et al. eds., 2000); JeanFrancois Flauss, La Cour europeenne des droits de l'homme est-elle une Cour constitutionnelle?, 36 Revue française de droit constitutionnel 711 (1998).

8. See generally Deborah Z. Cass, The Constitutionalization of the World Trade OrganizaTION (2005); Ernst-Ulrich Petersmann, The WTO Constitution and Human Rights, 3 J. Int'L Econ. L. 19 (2000); Joel P. Trachtman, The Constitutions of the WTO, 17 Eur. J. InT'L L. 623 (2006). 


\section{A. Defining "Constitution"}

Let us begin with what are arguably the most basic, primal notions of a constitution, one set drawn from the social sciences and the other from positivist legal theory. Social scientists across various disciplines have long recognized the fierce difficulties that human beings face in organizing themselves into self-governing and self-sustaining communities. Anthropologists and sociologists have identified certain necessary "starting mechanisms" for the creation of norm-based social systems, including legal systems. In my view, the most obvious of such mechanisms is the basic rule of reciprocity: "[p]romises made are to be kept; debts incurred are to be repaid; kindnesses received are to be recognized and returned." For Georg Simmel, reciprocity provides any group a "special consecration," connecting its members to "a common fate." 10 The idea that reciprocity helps to sustain a community over time has a long pedigree. ${ }^{11}$ Following this logic, reciprocity is the ultimate constitutional rule, and what we more commonly understand as "the constitutional law" is a means of formally consecrating the norm for particular needs and circumstances. ${ }^{12}$

From the vantage point of rational choice and game theory approaches to norms, any basic norm that allows actors to overcome collective action problems, and thus to build stable forms of cooperation, will appear to be constitutive of a community. ${ }^{13}$ In any event, some scholars now explicitly equate WTO constitutionalism with a bundle of reciprocity norms, and this view deserves to be taken seriously. ${ }^{14}$ One could also read the "constitutional" jurisprudence of the European Court of Justice (ECJ) and of the ECtHR as a sophisticated and constitutionalizing elaboration of a reciprocity rule: pacta sunt servanda, which means "agreements must be kept." ${ }^{15}$ Both the EU and the European Convention on Human Rights (ECHR) are

9. Stone Sweet, supra note 4, at 149. See generally Alvin W. Gouldner, The Norm of Reciprocity: A Preliminary Statement, in Friends, Followers, and Factions 28 (Steffen W. Schmidt et al. eds., 1977).

10. Georg Simmel, The Sociology of Georg Simmel 123, 135 (Kurt H. Wolff trans., 1950).

11. See, e.g., L.T. Hobhouse, Morals in Evolution: A Study in Comparative Ethics (1906); Bronislaw Malinowski, Crime and Custom in Savage Society (1959); A General Theory of Action (Talcott Parsons \& Edward A. Shils eds., 1951).

12. Consider as well the "constituting" role of the Ten Commandments of the Old Testament.

13. See generally Geoffrey Brennan \& James M. Buchanan, The Reason of Rules: Constitutional Political Economy (1985) (arguing against judicially-enforceable rights because they would invite the constitutional judge to alter ex ante bargains that comprise the constitutional contract).

14. See generally Carsten Herrmann-Pillath, Reciprocity and the Hidden Constitution of World Trade, 17 Const. Pol. Econ. 133 (2006).

15. Black's Law Dictionary 1140 (8th ed. 2004). 
multilateral treaty systems that have evolved to confer on individuals judicially enforceable rights that individuals can plead against states.

Legal positivists, for their part, have labored to distinguish modern legal systems from other normative systems and to identify those structural features that enable a legal system to perform its most important functions. A prominent example is H.L.A. Hart's claim that "pre-law" societies, communities governed by informal ("unofficial") norms and authority structures, were "inefficient" and prone to inertia, and even anomie, insofar as their regimes lacked what Hart called "secondary rules." Secondary rules are means of adapting norms to changing circumstances and of resolving disputes about the existence, and hence the validity and authority, of norms. ${ }^{16}$ Hart then defined a legal system as "a complex union of primary and secondary rules." ${ }^{\prime 7}$ The primary rules confer rights and duties on people and regulate their behavior. The secondary rules "specify the ways in which the primary rules may be conclusively ascertained, introduced, eliminated, varied, and the fact of their violation conclusively determined." 18 In Hart's account, the secondary rules provide a "remedy" for the "defects" that afflict prelegal regimes, such as inefficiency, stasis, and uncertainty; he proposes no other possible solution to the problems diagnosed by secondary rules. ${ }^{19}$ For present purposes, what matters is that secondary rules are typically developed as constitutional law and, as such, they enable a community to overcome the kinds of common governance problems identified by legal theorists and social scientists. ${ }^{20}$

Even those who are sympathetic to these kinds of arguments might nonetheless worry that they overstretch the concept of a "constitution," undermining its practical usefulness. They may argue that pushing for more abstract understandings of a "constitution" may lead us to find constitutions everywhere we see stable forms of social organization or every time we see secondary rules. However, at the

16. H.L.A. Hart, The Concept of Law 92-93 (2d ed. 1994).

17. Id. at 114 .

18. Id. at 94 .

19. Although I will not dwell on the matter, social scientists concerned with explaining economic growth and market integration would find these features of Hart's proposal familiar. See Douglass R. North, Institutions, Institutional Change, and Economic Performance (1990) (arguing that economic growth is partly a function of the capacity of law and courts to reduce the transaction costs of economic exchange); Stone Sweet \& Brunell, supra note 5 (showing that the growth of intra-EC trade and the "constitutionalization" of the EC legal system are causally interconnected).

20. I define governance as "the process through which the rules systems in place in any social setting are adapted to the needs and purposes of those who live under them." Stone Sweet, supra note 4, at 147. 
same time, the specific qualities that make politico-legal systems "constitutional" might remain obscure or unappreciated.

I prefer a definition that builds upon Hart's secondary rules as applied to the state, and one that does not conflict in any significant way with definitions developed by others, including Joseph Raz. ${ }^{21}$ Thus, I define a constitution as a body of meta-norms, those higher-order legal rules and principles that specify how all other lower-order legal norms are to be produced, applied, enforced, and interpreted. Meta-norms constitute political systems in perpetuity. In today's world, written constitutions are the ultimate, formal source of state authority. They establish governmental institutions, such as legislatures, executives, and courts, and grant them the power to make, apply, enforce, and interpret laws. Constitutions tell us how infra-constitutional norms, like statutes, are to be made. They establish lawmaking procedures and determine how legislative authority is constituted through, for example, elections, and what the legislature can do, by enumerating powers. Even if only ideally, constitutions also indicate how the various governmental institutions are expected to interact with one another through, for instance, separation of powers doctrines. New constitutions-those written over the past sixty years-also usually contain a catalogue of rights which are, by definition, substantive constraints on government. These new constitutions also establish procedures and institutions for protecting rights against governmental incursion, typically in the form of a supreme or constitutional court.

\section{B. Defining "Constitutionalism"}

In contrast to defining "constitution," it may be impossible to define the concept of "constitutionalism" in a relatively consensual, straightforward way. My preferred definition of constitutionalism denotes the commitment on the part of any given political community to be governed by constitutional rules and principles. Thus, constitutionalism is a variable. The commitment to live under a constitution, rather than to seek to undermine or destroy it, varies. In any context, this commitment, as an indicator of a constitution's social legitimacy, can be strong or weak and its character can change over time.

21. The constitution, inter alia, "defines the ... powers of the main organs of the different branches of government": "it is, and is meant to be, of long duration"; "it has a canonical formulation" (that is, it is codified and purports to be comprehensive); it "constitutes a superior law" that is "justiciable"; and amendments to it are "legally more difficult to secure than ordinary legislation." Joseph Raz, On the Authority and Interpretation of Constitutions: Some Preliminaries, in Constitutionalism 152, 153 (Larry Alexander ed., 1998). 
Others use constitutionalism to refer to those practices and understandings of government that are derivable from, or inhere in, any particular constitutional order. As Neil Walker suggests, "[c]onstitutionalism is the set of beliefs associated with the idea of constitutional government."22 For example, the French would emphasize the organic unity of the People and the General Will; Americans would focus on federalism and checks and balances between the branches of government; Canadians might emphasize the value of multiculturalism. Another constitutional theorist, Ulrich Preuss, defines constitutionalism as "the basic ideas, principles, and values of a polity [that] aspires to give its members a share in the government." ${ }^{23}$ In this view, the analyst focuses on what Joseph Raz identifies as the "thick" elements of a constitution: ${ }^{24}$ those foundational notions of how, "in our political system," "we” organize the state, constitute our government, provide for representation and participation, protect minorities, promote equality, and so on. Here again, constitutionalism will vary; institutional arrangements and public policies that are viewed as legitimate, or even required, in one country may be considered unacceptable in another.

It is worth noting other definitions. For the political scientist, Carl Friedrich, constitutionalism refers to "limited government," situations wherein the higher law "effective[ly] restrains" those who control the coercive instruments of the state. ${ }^{25}$ Koen Lenaerts, a law professor and a judge on the European Court of First Instance, similarly defines constitutionalism as "limited government operating under the rule of law." ${ }^{26}$ Michel Rosenfeld, editor of the International Journal of Constitutional Law, notes that "there appears to be no accepted definition of constitutionalism," but then states that "modern constitutionalism requires imposing limits on the powers of government, adherence to the rule of law, and the protection of fundamental rights." ${ }^{27}$ We will return to the "limited government" formulation shortly, but for now it is enough to note that constitutions do not just limit state power; they constitute and enable state power.

22. Neil Walker, European Constitutionalism and European Integration, Рuв. L., Summer 1996, at $266,267$.

23. Ulrich K. Preuss, The Political Meaning of Constitutionalism, in Constitutionalism, Democracy and Sovereignty: American and European Perspectives 11, 12 (Richard Bellamy ed., 1996).

24. Raz, supra note 21 , at 154.

25. Carl J. Friedrich, Constitutional Government and Democracy 24 (1950).

26. Koen Lenaerts, Constitutionalism and the Many Faces of Federalism, 38 Aм. J. Comp. L. 205, 205 (1990).

27. Michel Rosenfeld, Introduction: Modern Constitutionalism as Interplay Between Identity and Diversity, in Constitutionalism, Identity, Difference, and Legitimacy: Theoretical Perspectives 3, 3 (Michel Rosenfeld ed., 1994). 
Still, others take an even thicker, cultural view of constitutionalism, conceiving it as an overarching ideology of politics, community, citizenship, and the state. In this tradition, constitutions are analyzed in terms of their capacity to express the collective identity of a specific people through their values, aspirations, and idealized essence. ${ }^{28}$ To these scholars, a robust constitutionalism is a well-spring of legitimizing resources for the body politic, helping it to evolve as circumstances change. In contrast, a weak constitutionalism fails to represent collective identity and fails to reconstruct the legitimacy of the state in times of crisis.

Many notions of constitutionalism are explicitly normative, emphasizing the good or proper functions that a constitution is alleged to perform, such as limiting government, embodying political ideals, and expressing collective identity. However, I define a constitution without reference to the "good" or "proper." Again, a constitution is a specific cluster of meta-norms, those systemically-constitutive rules and principles that guide us on how all other lower-order legal norms are to be produced, applied, and interpreted. Thus, where we see meta-norms, we observe a constitution. ${ }^{28}$ Again, I prefer to conceptualize constitutionalism as the commitment of a polity to govern itself in conformity with the meta-norms.

\section{The Interrelationship between Constitutions and Constitutionalism}

Constitutions and constitutionalism vary across time and place. A constitution can be "bad" for democracy, with meta-norms establishing dictatorship and a polity's constitutionalism actually legitimizing authoritarianism. In world history, one finds far more examples of constitutional regimes that have failed to sustain limited government and participatory democracy than examples of success. Further, no obvious or necessary correlation exists between a stable community's "collective identity" and the social legitimacy of any legal system, constitution, or state. Many obvious examples evidence this disconnect, even among relatively resilient Western states. Some "nations" or societies possess strong collective identity, but have neither a constitution nor a state (for example, the Basques). Other constitutional regimes, such as Canada, are relatively robust, despite cultural heterogeneity and weak collective identity. Some supposedly strong cultural systems-France, for example-have experienced constitutional chaos over centuries. France has

28. See, e.g., Sheldon S. Wolin, The Presence of the Past: Essays on the State and the Constitution (1989); Jo Shaw, Postnational Constitutionalism in the European Union, 6 J. Eur. Pub. PoL'y 579 (1999); Robert Post, Democratic Constitutionalism and Cultural Heterogeneity (Univ. Cal. Berkeley, Inst. of Govt'l Studies Working Paper, 2000), available at http://repositories.cdlib.org/boaltwp/108. 
had fifteen different constitutions since the Great Revolution of 1789. The people composing some strong cultural systems, such as the Italians, might view the supranational government of the EU with more regard than their own political system. These are but a few examples. The extent to which any constitutional regime is based on a strong identity, whether "collective," "cultural," or "constitutional," is an empirical question to which there may be no straightforward, empirically-based answer. Moreover, the extent to which a state survives over time may or may not have anything to do with the stability of a constitutional order. Constitutions may come and go, whereas the state may persist. Likewise, states may disappear but the people may survive.

The variance one finds in the empirics of comparative constitutional law ought to matter a great deal to debates about the constitutionalization of international law and regimes. For example, states' constitutions, the meta-norms, have differed a great deal in their capacity to constrain the authority of lawmaking organs. To see this, consider the following typology of constitutions.

\section{Type 1: The Absolutist Constitution}

In the absolutist constitution typology, the authority to produce and change legal norms, including the constitution, is centralized and absolute. Meta-norms reflect, rather than restrict, the absolute power of those who govern. In Europe, the archetype of this kind of constitution is the French Charter of 1814, which other monarchies, especially in the Germanic states, widely imitated. As seen in the Charter, absolutist constitutions reject popular sovereignty, rights, and viable separation of powers. ${ }^{29}$ In the twentieth century, many constitutions that appeared to establish full-scale constitutional democracies in fact functioned as single-party or one-man dictatorships. Examples include the Union of Soviet Socialist Republics, many Central European states under Communist Party control, and states resulting from military coups in Asia, Africa, and Central and South America. Although less prevalent today, there have been a handful of post-1980 constitutions that expressly enshrined the one-person or one-party rule of government, including the constitutions of Sri Lanka, Togo, and Niger.

\section{Type 2: The Legislative Supremacy Constitution}

In legislative supremacy constitutions, the constitution provides for a stable set of governmental institutions and elections for the legislature. Elections legitimize

29. See Horst Dippel, Modern Constitutionalism, An Introduction to a History in the Need of Writing, 73 Legal Hist. Rev. 153, 162 (2005). 
legislative authority and in turn, legislative majorities legitimize statutory authority. Once adopted by the legislature, statutes are commands until abrogated by subsequent legislation. The crucial meta-norm is the rule of legislative sovereignty, which has a number of important consequences.

The first is that the constitution is not entrenched-that is, no special, nonlegislative procedures exist for revising it. Instead, the constitution can be changed through a majority vote of the legislature. ${ }^{30}$ The second consequence is that any act that conflicts with a statute is itself invalid. Judicial acts are subject to this rule, and thus the judicial review of statutes is prohibited. The third is that the constitution contains no layer of substantive constraints in the form of rights. Rights are, in effect, granted by the legislature in statutes. Relatively pure examples of this type of constitutional system include the Australian parliamentary system, the British system through much of the twentieth century, and the French Third (1875-1940) and Fourth (1946-1958) Republics.

\section{Type 3: The "Higher Law" Constitution}

The final constitutional typology is the "higher law" constitution. This type of constitution and the legislative supremacy constitution both establish state institutions and link these institutions to society via elections. However, the higher law constitution adds substantive constraints to the exercise of public authority in the form of fundamental rights and establishes independent, judicial means of enforcing rights, even against legislative authority. Thus, legislative sovereignty is expressly rejected. Further, the higher law is entrenched with this type of constitution specifying amendment procedures which, typically, make it more difficult to change the constitution. As an empirical matter, the legislative supremacy constitution is virtually extinct, having been replaced by the higher law constitution. ${ }^{31}$

The thrust of my argument, to this point, is that the legal systems of certain treaty regimes, especially those of the EU, the ECHR, and WTO, are constitu-

30. In 1911, for example, the British House of Commons abolished the veto of the House of Lords, removing the last important constraint on its own lawmaking powers. Harry Jones, LiBeralism and the House of Lords: The Story of the Veto Battle, i832-igi i, at 7 (1912).

31. By the 1990s, the basic formula — a written, entrenched constitution, a charter of rights, and a review mechanism to protect rights - had become standard, even for what most of us would consider authoritarian states. There are 194 states in a recent data set on constitutional forms compiled by Christina Andersen and Alec Stone Sweet. Of these, 190 have written constitutions, of which 183 contain a charter of rights. There have been 114 constitutions written since 1985 (not all of which still exist), and we have reliable information on 106 of these. All 106 of these constitutions contain a catalogue of rights, and 101 provide for rights review by a supreme or constitutional court. It seems that the last constitution to leave rights out was the racist 1983 South African constitution, hardly a model to emulate. 
tional; they are constituted, like the systems of virtually all nation-states today, by written meta-norms or codified secondary rules. Further, these regimes are built on a normative foundation that is very similar to higher-law constitutions. The highest courts of each of these systems exercise compulsory jurisdiction over disputes that arise under their respective treaties and their authority to interpret and apply the regime's law is final. As I will argue in Part III, these courts are not only constitutional courts, but powerful constitutional courts.

In my view, these claims are not trivial. Mainstream international relations scholarship long denied the capacity of international organizations to develop autonomous capacities to produce, monitor, and enforce legal norms. ${ }^{32}$ For their part, public international lawyers waited decades before the appearance of international regimes that included courts capable of exercising judicial review of state acts with reference to treaty law on the basis of compulsory jurisdiction. The emergence and institutionalization of hierarchies has transformed international law and politics.

\section{On Constitutional Pluralism}

Those who ponder the constitutionalization of international law disagree on a number of fundamental points. Yet, there does appear to be emerging consensus on the idea that the more pluralistic the juridical authority structure of the system, the more difficult or impossible it will be to argue that the system has a constitutional basis. ${ }^{33}$ In this part, I challenge this view. First, I provide two versions of what I will call constitutional pluralism. Each considers both the pluralistic and constitutional attributes of a system. Second, I discuss the extensive pluralism one finds in national constitutional orders, focusing on the structure of constitutional authority in a handful of Western European states. I ultimately argue that the most important factor is determining whether the tensions that inhere in systemic pluralism trigger processes that produce a meaningful constitutionalization of the system.

\section{A. Constitutional Pluralism}

The view that, for any given system, any measure of legal pluralism is inversely proportional to any measure of constitutional order has several implications. At the pluralist extreme, there might be no legal "system" at all beyond the facts of plural-

32. The international relations literature is surveyed in Stone, supra note 2.

33. For an overview of the scholarly debate on this issue, see Gráinne de Búrca, Europe's Judicial Resolution and the UN Security Council 34-42 (on file with author). 
ism. At the other extreme, one might find a hierarchically-constructed legal system where pluralism has been extinguished beyond how the constitution itself recognizes diversity and distributes lawmaking discretion to various organs. It is not clear to me how one might construct a continuum between these two poles. The pluralist-constitutionalist dichotomy might constitute different ways of describing measures of the same variable, or they may need to be decoupled insofar as they comprise separate variables with the potential to interact with one another.

In this section, I sketch a perspective that considers the international system's pluralist and constitutionalist features simultaneously. In at least two ways, the phrase "constitutional pluralism" might be a useful description of the present system rather than a theoretical impossibility or oxymoron. The first way to conceptualize constitutional pluralism emphasizes how constitutional orders are organized within a system that is otherwise pluralist, or anarchic, in the sense that the system is not one of sovereign governance. Within this pluralist system, one observes discrete islands of hierarchy and constitutionalism; this observation can be made with respect to the EU and WTO. The increasing complexity of norms and forms of international governance and the transnational nature of many regulatory problems means that these orders inevitably come into contact with one another and, at times, with national constitutional orders. ${ }^{34}$ The interaction of these autonomous legal orders will partly determine how the overall system will develop. ${ }^{35}$ And the system may well develop in ways that are meaningfully constitutional.

A second way of conceptualizing constitutional pluralism begins with describing what is "constitutional" before describing what is "pluralistic." Some constitutionalists point to or seek to construct a body of higher-law, international legal norms. The most invoked norms are, in fact, meta-norms such as jus cogens norms, basic human rights, and procedural guarantees associated with due process and access to justice. ${ }^{36} \mathrm{~W}$ ithin this overarching normative frame of a theoretically-supposed constitution, one finds discrete hierarchies, both national and

34. Neil Walker, Beyond Boundary Disputes and Basic Grids: Mapping the Global Disorder of Normative Orders, 6 Int'L J. Const. L. 373, 382 (2008).

35. For a survey of the mechanisms and processes for upgrading the common interest under conditions of legal pluralism, see Paul Schiff Berman, Global Legal Pluralism, 80 S. CaL. L. Rev. 1155, 1196-1234 (2007).

36. Although they might object, I read Erica de Wet and Ulrich Petersmann to be representative of this view. See Erica de Wet, The International Constitutional Order, 55 InT'L \& Comp. L.Q. 51, 57-63 (2006); Ernst-Ulrich Petersmann, Multilevel Trade Governance Requires Multilevel Constitutionalism, in Constitutionalism, Multilevel Trade Governance and Social Regulation 5 (Christian Joerges \& Ernst-Ulrich Petersmann eds., 2006). 
treaty-based. The systems within the hierarchies interact with one another with reference to the overarching frame. One can then focus again on the dynamics of pluralist interaction on inter-regime conflict, resistance, diplomacy, and cooperation to find evidence that the system is indeed constitutional and to identify mechanisms of systemic construction.

These two ways of thinking about constitutional pluralism are not mutually exclusive. As an empirical matter, the interactions between legal systems, under conditions of pluralism, may be generative of norms that gradually congeal as constitutional norms.

A strong claim I make in this section is that constitutional pluralism, in the second sense of the term, describes a systemic condition that is not restricted to the international system. In Europe, the evolution of higher-law constitutionalism is largely a narrative of constitutional pluralism. I doubt that many important exceptions exist anywhere else on the globe. Legal pluralism, even within highly developed national legal orders, is never extinguished, and may, in fact, remain quite robust. I believe this fact fatally undermines the idea that pluralistic orders are qualitatively different than constitutional orders and that comparative constitutional law is irrelevant to the concerns of international law when it comes to the pluralist-constitutionalist debate. Here, I will make only a few basic points with reference to rights protection in Europe. I will focus on the legal systems of France, Germany, Italy, and Spain, first on their own, and then analyze how each interacts with European law.

\section{B. Constitutional Pluralism in National Constitutional Orders of Western Europe}

\section{Analysis of National Constitutional Orders Individually}

The most recent constitutions of these four states confer on constitutional courts the exclusive authority to invalidate legislative statutes. At the same time, the judicial review of statutes by the "ordinary," non-constitutional courts remains prohibited. The task of the ordinary courts is to enforce statutes, while the constitutional courts defend the primacy of the constitution, especially fundamental rights, against legislative encroachment. In Germany, Italy, and Spain, ordinary judges have an indirect role in the "concrete review" of statutes; they possess the discretionary power to refer to the constitutional court those statutes they believe warrant scrutiny pursuant to litigation at bar. In France, a 2008 revision of the constitution gave, for the first time, the two French supreme courts the same authority. In Germany and Spain, but not in Italy or France, individuals who believe a public authority, includ- 
ing a court, has violated their rights can send a constitutional complaint directly to the constitutional court once other remedies have been exhausted. ${ }^{37}$

The legal systems of each of these states can be characterized as pluralist: jurisdiction is fragmented rather than unified and final authority to determine outcomes is distributed among autonomous supreme courts that manage functionally-specialized legal domains. These domains are typically verticallyintegrated hierarchies that are insulated in various ways from the authority of the constitutional courts. In each of the four states, this structure of legal pluralism inevitably raised certain crucial constitutional questions. But pluralism meant that these questions could not be answered in any fixed or pre-determined way. To what extent do constitutional rights "radiate" from the constitution to permeate other domains of law? If the power to invalidate a law as unconstitutional is exclusive to the constitutional judge, then to what extent can or should the ordinary judge interpret and apply the constitution on her own? If the constitution binds the exercise of all public authority, including judicial authority, to what extent is the case law of the constitutional court binding on the ordinary courts? In Europe, these and many other important questions arise under the rubric of a debate commonly labeled the "constitutionalization of the law." ${ }^{38}$

Simplifying what is a complex set of dynamics, constitutional courts have labored to constitutionalize the legal order with mixed results. For example, in its Lüth decision, the German Federal Constitutional Court (GFCC) famously ordered the civil courts to give effect to rights and to the GFCC's rights jurisprudence in their application of the German Civil Code. ${ }^{39}$ Resistance and a long struggle with the ordinary supreme court ensued and continues through today. ${ }^{40}$

37. Constitutional courts in all four countries undertake "abstract review" of laws pursuant to referrals from certain constitutionally designated elected officials. These referrals are akin to a "facial challenge" in the United States in that they result in the constitutional review of a law prior to its enforcement.

38. Alec Stone Sweet, Governing with Judges: Constitutional Politics in Western Europe $116-17(2000)$.

39. See Bundesverfassungsgericht [BVerfG] [Federal Constitutional Court] Jan. 15, 1958, 7 Entscheidungen des Bundesverfassungsgericht [BverfGE] 198 (1958) (F.R.G.); Mattias Kumm, Who is Afraid of the Total Constitution? Constitutional Rights as Principles and the Constitutionalization of Private Law, 7 German L.J. 341, 346-51 (2006).

40. For commentary on two recent GFCC rulings, see generally Federal Constitutional Court Affirms Horizontal Effect of Constitutional Rights in Private Law Relations and Voids a Marital Agreement on Constitutional Grounds, 2 German L.J. (2001), http://www.germanlawjournal.com/ article.php? id=61; Peer Zumbansen, Federal Constitutional Court Rejects Ban on Benetton Shock Ads: Free Expression, Fair Competition, and the Opaque Boundaries Between Political Message and Social Standards, 2 German L.J. (2001), http://www.germanlawjournal.com/article.php?id=14. 
Even when ordinary judges do choose to interpret the Civil Code in light of the constitution, they can refuse to send references to the GFCC when asked to do so by litigants. Nonetheless, in any specific conflict with an ordinary court, like the supreme court, the GFCC has the resources to impose its choice as to how rights must be applied to resolve a particular conflict under the Civil Code. It can do so pursuant to a constitutional complaint but only by stepping with both feet into the private law judge's presumptively exclusive domain. The GFCC then sifts through the facts, reweighs the values and interests in conflict, and quashes the judge's decision. In Germany today, more than 90 percent of all individual complaints are de facto appeals of judicial decisions that allegedly conflict with the constitution or the GFCC's case law. Also, in Spain, constitutionalization has depended critically on the amparo, the individual complaint. Again, as constitutionalization has proceeded, so too has the intensity of the conflict between the Spanish Constitutional Tribunal and the ordinary supreme court. ${ }^{41}$ In Germany and Spain, then, we find a great deal of constitutional pluralism. Confronting and managing the friction inherent in plural environments allows constitutionalization to proceed.

The Italian Constitutional Court (ICC) has been far less successful in expanding the authority of both the Court and the constitution within the legal system as a whole. Unlike the situation in Germany and Spain, in Italy, individuals are unable to go to the constitutional judge when the ordinary courts fail either to refer a law to the ICC or to properly apply the ICC's rights jurisprudence. Though I will not go into detail, it is evident that the capacity of the ICC to exert its authority, and the authority of the constitution, depends critically on its ability to negotiate a cooperative relationship with the supreme civil court - the Corte di Cassazione-and the supreme administrative court - the Consiglio di Stato. But, cooperation is not guaranteed. Indeed, "wars of judges," large and small, periodically break out between the ICC and the other supreme courts. These wars occur because the ICC lacks the means to impose its authority on the ordinary high courts, while the latter have asserted their own authority to control the law and to develop the constitution. ${ }^{42}$

\footnotetext{
The intensity of the scholarly debate on these issues shows no sign of relenting. See generally CuausWilhelm Canaris, Grundrechte und Privatrecht - eine Zwischenbilanz (1999); Uwe Diederichsen, Das Bundesverfassungsgericht als oberstes Zivilgericht - ein Lehrstück der juristischen Methodenlehre, 198 Archiv für die civilistische Praxis 171 (1998).
}

41. See Stone SweEt, supra note 38, at 119-21.

42. See id. at 121-22. 


\section{Analysis of National Constitutional Orders' Interaction with European Law}

Let us now turn to how the four national legal orders this article has discussed have interacted with European law. Scholars have shown, conclusively in my view, that these interactions have accentuated the legal pluralism of national constitutional systems, while enhancing the constitutional features of European law. Once incorporated into national legal orders, the ECJ's constitutional doctrines, such as supremacy ${ }^{43}$ and direct effect, ${ }^{44}$ conferred on all national judges the power to review the legal validity of national statutes with reference to EC law at the behest of litigants. These same doctrines imposed a duty on national judges to refrain from applying any national law found to be in conflict with an EC norm. In many countries, lower court judges exploited these doctrines to assert new powers and to undermine the authority of appellate courts and constitutional courts. ${ }^{45}$ Clashes between the ordinary courts and constitutional courts, and between the constitutional courts and the ECJ, followed.

Perhaps the most well-known of these clashes pitted the GFCC against the ECJ. The GFCC noticed that accepting the supremacy of EC law would open a gap in national rights protection in any domain where legislative competence had been transferred to the EC, given that the Treaty of Rome contained no charter of rights. This conflict could have resulted in the death of the ECJ's supremacy doctrine. However, it gradually evolved into an intricate set of "dialogues" known as the Solange saga. ${ }^{46}$ The GFCC and the ECJ engaged one another in constitutional terms. Among other important outcomes, the ECJ moved to incorporate a body of funda-

43. The doctrine of supremacy, first announced in 1964, mandates that an EC legal decision has primacy in any conflict between an EC legal rule and a national legal rule. See Case 6/64, Costa v. ENEL, 1964 E.C.R. 585, 599-600, 614-15. In 1978, the European Court of Justice (ECJ) held that every EC norm, from the moment it entered into force, "render[s] automatically inapplicable any conflicting provision of ... national law," including national constitutional rules. Case 106/77, Amministrazione delle Finanze dello Stato v. Simmenthal, 1978 E.C.R. 629, 643.

44. Through the doctrine of direct effect, EC norms provide individuals with legal rights that public authorities must respect, and which can be pleaded in the national courts. In 1963, the ECJ held that provisions of the Treaty Establishing the European Economic Community were directly effective. See Case 26/62, Van Gend en Loos v. Nederlandse Administratie der Belastingen, 1963 E.C.R. 1, 16. Furthermore, the ECJ later held in 1974 that a class of secondary legislation, called “directives," was, under certain conditions, also directly effective. See Case 41/74, Van Duyn v. Home Office, 1974 E.C.R. 1337, 1347-49.

45. See J.H.H. Weiler, A Quiet Revolution: The European Court and Its Interlocutors, 26 Comp. Pol. STud. 510, 523 (1994).

46. For an extensive commentary on the Solange saga, see Julianne Kokott, Report on Germany, in The European Courts and National Courts: Doctrine and Jurisprudence 77, 117-27 (AnneMarie Slaughter et al. eds., 1998). 
mental rights into the Treaty of Rome as unwritten general principles inspired by the ECHR and the "constitutional traditions" in place in the member states. This is just one illustration, among many, of how the dynamics of legal pluralism can generate a situation better qualified as constitutional pluralism.

Today, in Europe, national and European (EC and ECHR) norms overlap one another. These norms are constitutional insofar as they span across hierarchies to the extent that they are overarching and shared. Because multiple high courts assert final jurisdiction over these norms, the wider system is pluralistic. ${ }^{47}$ However, as we find in many national systems, the constitutionalization of the overall system has been a function of how courts, and sometimes other governmental organs, manage legal pluralism. Outcomes were not predetermined by positive law. Constitutionalization was, instead, the product of a complex social process, mediated by autonomous bodies of law, in which courts and other legal elites worked to find accommodations that ultimately served to reveal, and then to steadily upgrade, the constitutional elements in the system.

The French case offers an extreme example of fragmented judicial authority and constitutional pluralism. French Republican "constitutional identity" has traditionally been described with reference to the doctrine of the indivisibility of the "Nation," which is represented by Parliament, and the doctrine of the sovereignty of the General Will, which is incarnated in parliamentary statutes. ${ }^{48}$ Of course, these doctrines denied any meaningful measure of legal pluralism in the system. Further, until a 2008 constitutional amendment, the French Constitutional Council (Constitutional Council) only possessed the power of "abstract review," the pre-enforcement control of legislation upon referral by certain high state officials and any sixty deputies or senators. The Constitutional Council had no other authority to control the constitutionality of statutes or other norms. Once promulgated, statutes were immune from any further form of review under the separation of powers doctrines that undergird the ideology of the General Will, which valued legislative sovereignty and the prohibition of judicial review. Further, the Constitutional Council had no formal connections to the judiciary. Its review powers touched only upon the exercise of legislative authority prior to a statute's entry into force.

47. For superb analysis of constitutional pluralism in Europe that focuses on the interactions between national constitutional courts and the European Convention on Human Rights, see generally Lech Garlicki, Cooperation of Courts: The Role of Supranational Jurisdiction in Europe, 6 INT'L J. Const. L. 509 (2008); Nico Krisch, The Open Architecture of European Human Rights Law, 71 Mod. L. Rev. 183 (2008).

48. See Alec Stone, The Birth of Judicial Politics in France: The Constitutional Council in Comparative Perspective 24-31 (1992). 
In the 1970s, however, against the will of the founders, the Constitutional Council directly incorporated into the Constitution various rights texts mentioned in the Preamble of the 1958 Constitution and asserted jurisdiction over these rights. In the 1980s, the Constitutional Council began to build a more sophisticated, rightsbased constitutional jurisprudence, some of which was directed at the ordinary courts. Among other innovations, it began issuing réserves stricts d'interprétation, saving constructions meant to bind the courts to its application of the law. ${ }^{49}$ Notoriously, the High Administrative Court, the Conseil d'état, and the Supreme Court, the Cour de cassation, reacted by refusing to recognize the authority of the Council's reasoning. ${ }^{50}$ Diplomacy proceeded, and by the end of the 1990 s, senior judges on the Cour de cassation and the Conseil d'état chose to accept, when it suited them, the "persuasive authority" of the Constitutional Council's interpretations. Neither high court accepts the Constitutional Council's opinions as formally binding. ${ }^{51}$

At the same time, both courts began to assert their own autonomous authority to interpret constitutional rights. ${ }^{52}$ During the Fourth Republic (1946-1958), the Conseil d'état developed, under the banner of "general principles of law," various restrictions on administrative action. Most of these principles, including "individual liberty," "equality before the law," "freedom of conscience," and "non-retroactivity," functioned, as de facto rights. In the 1980s, the Conseil d'état began to convert them into de jure rights, thus securing their permanence and higher law status. It shielded itself by following the Constitutional Council's lead. In 1996, the Conseil d'état took the momentous step of constitutionalizing a new constitutional principle on its own, without prior authorization by the Constitutional Council. For its part, the Cour de cassation began to engage in a new form of statutory review, which the French call "the constitutional correction of legal norms." ${ }^{33}$ Ordinary judges are now obliged to interpret provisions of the codes as if they were in harmony with constitutional rights.

Now, let us consider this situation of French constitutional pluralism with respect to European law. In 1975, the Constitutional Council made a strategic error that no other national constitutional court has made: it declared that the

49. Id. at 66-69.

50. In 1993, l'Association Professionnelle des Magistrats released a Communiqué calling on judges and prosecutors to ignore binding interpretations, which they characterized as "trivial" gloss. LE Monde (Paris), Aug. 9, 1993.

51. Alec Stone Sweet, Le Conseil constitutionnel et la transformation de la République, 25 CAHIERS du Conseil Constitutionnel 65, 68 (2008).

52. See Stone Sweet, supra note 38, at 124-25.

53. Id. at 123. 
ECHR fell entirely outside the scope of its jurisdiction..$^{54}$ In the beginning, the Cour de cassation and the Conseil d'état resisted the invitation to become judges of the "conventionality" of French legal norms, not the least due to the principle of separation of powers. Ultimately, they chose to incorporate the ECHR into French law, giving it a rank superior to statute, ${ }^{55}$ and then gradually began to enforce it. In my view, they did so in order to defend themselves against censure at the hands of the ECtHR and to develop and consolidate a new powers-of-rights review.

Thus, over the past fifteen years, the Cour de cassation and the Conseil d'état gradually became de facto constitutional judges. They interpret and apply constitutional rights and the ECHR, and they do so beyond the reach of the control of the Constitutional Council and the Parliament. Further, each of the two "ordinary" supreme courts now perform the inherently constitutional task of coordinating French law and European law, including rights doctrines, with one another. For its part, given the increasing importance of the ECHR within the French legal order, the Constitutional Council must either reverse its 1975 jurisprudence or risk increasing marginalization. The 2008 constitutional revision, enabling the high courts to send the Constitutional Council laws for as-applied review, formally destroyed the ideology of the General Will. It also introduced an Italian-style system of concrete review known as l'exception d'inconstitutionnalité. If the Italian example is any guide, the reform is likely to accentuate, rather than reduce, constitutional pluralism in France. ${ }^{56}$

\section{Constitutional Jurisdiction}

Once a community, whether national or international, decides to create a higher law constitutional system, the problem is how to guarantee the higher law's normative integrity and supremacy. The higher law constitution solves this problem by establishing a judicial, third-party mechanism for assessing the legality of

54. CC Decision no. 74-54DC, Jan. 15, 1975, Rec. 19, available at http://www.conseil-constitutionnel.fr/conseil-constitutionnel/francais/les-decisions/depuis-1958/decisions-par-date/1975/7454-dc/decision-n-74-54-dc-du-15-janvier-1975.7423.html.

55. Article 55 of the French Constitution provides for the primacy of treaty law over statute. 1958 Const. 55. Prior to 1989, French courts initially refused to enforce treaty law when it came into conflict with statutes adopted later in time on grounds of separation of powers. See Elisabeth Lambert Abdelgawad \& Anne Weber, The Reception Process in France and Germany, in A Europe of Rights: The Impact of the ECHR on National Legal Systems 105, 115-16 (Alec Stone Sweet \& Helen Keller eds., 2008). For an account of the effect of incorporating the Convention into national law, see $i d$. at 126-31.

56. See Stone Sweet, supra note 51, at 68. 
all other legal norms with reference to the constitution. In the standard form, the meta-norms establish a constitutional jurisdiction to perform this function. The ECHR, the EU, and the WTO have all done so. Among other things, the treaties establishing the ECtHR, the WTO, and the EU lay down state obligations that are subject to a judicial mechanism of enforcement. In each, the jurisdiction of the regime's high court is compulsory. Further, the highest courts of the WTO (the Appellate Body (AB)), the EU (the ECJ), and the ECtHR possess the final authority to interpret the treaties, including the scope of the court's own competence to review the conformity of national law with that of the regime. ${ }^{57}$

Within their own orders, these three courts typically possess more authority than most national courts. This point can be formalized in terms of a theoretical zone of discretion: the institutional basis of the strategic environment in which any court operates. ${ }^{58}$ This zone is determined by the sum of powers delegated to the court and possessed by the court as a result of its own accreted rulemaking through the building of precedent minus the sum of control instruments available for use by non-judicial authorities to shape, by constraining, or to annul, by reversing, outcomes that emerge as the result of the court's performance of its delegated tasks.

In a system of legislative sovereignty, an ordinary court's zone of discretion is relatively narrow: the legislature can overrule the court's decisions by creating or changing a statute using normal legislative procedures. National constitutional courts operate in a much wider zone of discretion, given their power to invalidate infraconstitutional norms and the decision rules governing constitutional amendment, which are typically more complex and more restrictive than a majority vote of a legislature. A peculiarity of treaty law, relative to most national legal systems, is that the decision rule governing the revision of the basic norms is unanimity, as is the case in each of our three examples. Unanimity is a highly restrictive rule that favors the dominance of the constitutional court over the evolution of the constitutional law.

Mapping a zone of discretion cannot tell us what constitutional courts will actually do with their powers. The best we can do is to predict that, given a steady case load, constitutional judges operating in a relatively larger zone will come to exercise more influence over the evolution of the polity than those operating in relatively

57. In Part II, I emphasized the differences between the systems; in this section, I focus on common features of the ECHR, EU, and World Trade Organization (WTO) legal systems. These systems, like constitutional systems more generally, vary in many crucial ways. However, these variations are not my concern here.

58. For a discussion of the "zone of discretion," see Alec Stone Sweet, Constitutional Courts and Parliamentary Democracy, 25 W. Eur. Pol. 77, 92-93 (2002); Mark Thatcher \& Alec Stone Sweet, Theory and Practice of Delegation to Non-Majoritarian Institutions, 25 W. Eur. PoL. 1, 5-7 (2002). 
smaller zones. The prediction, of course, is testable in comparative case studies. We should not expect our predictions always to be accurate because a zone of discretion does not take into account many factors that will be important in particular contexts. With that said, research of this kind would explain a great deal about comparative constitutional politics, such as why some systems are more effective than others.

No one has undertaken systematic comparative work on the effectiveness of constitutional review, so what follows in this article is tentative at best. In my view, any constitutional review mechanism can be said to be effective only to the extent that important constitutional disputes arising in the polity are brought to the reviewing authority on a regular basis, that the judges who resolve these disputes give reasons for their rulings, and that those who are governed by the constitutional law accept that the court's rulings have some precedential effect. Effectiveness will thus vary across states or legal systems, and across time in the same state or system.

Most review systems throughout world history have been relatively ineffective, even irrelevant. In weak systems, important political disputes may not be sent to constitutional judges for resolution, and decisions that constitutional judges do render may be ignored. Political actors may seek to settle their disputes by force rather than through the courts, sometimes with fatal consequences for the constitutional regime. Put simply, elites may care much more about staying in power at any cost for self-interested reasons, than they care about building constitutional democracy. Constitutional regimes may also be overthrown by force. Since 1950, in Africa, Central and South America, and Asia, one finds over one hundred examples. In some countries, the military coup d'état remains a constant threat. Between 1997 and 2006, there were at least twenty-five coup attempts in these areas and at least fourteen were successful, including in Ecuador, Fiji, Guinea-Bissau, the Ivory Coast, Mauritania, Pakistan, Thailand, and Turkey. None of these proceeded with respect to constitutional principles. Despite the odds, some courts and constitutions have operated as constraints even on military dictatorship. ${ }^{59}$

Where constitutional review systems are relatively effective, constitutional judges manage the evolution of the polity through their decisions. There are several conditions necessary for the emergence of effective review systems; each condition is related to the court's jurisdiction and zone of discretion. First, constitutional judges must have a caseload. If actors, private and public, conspire not to activate review, judges will be unable to develop influence over the polity. Second, once activated,

59. See Robert Barros, Constitutionalism and Dictatorship: Pinochet, the Junta, and the i98o Constitution 36-40, 87-88, 96-98 (2002). See generally Tamir Moustafa, The Struggle for Constitutional Power: Law, Politics and Economic Development in Egypt (2007). 
judges must resolve disputes and give defensible reasons in justification of their decisions. If they do, one output of constitutional adjudication will be the production of constitutional case law, which is a record of how judges have interpreted the constitution. Third, those who are governed by the constitutional law must accept that constitutional meaning is, at least partly, constructed through judges' interpretations and rulemaking and must use or refer to relevant case law in future disputes.

As an empirical matter, in comparison with all currently operating systems of constitutional review, or relative to all those that have operated over the past century, it is clear that the ECJ, the ECtHR, and the AB are among the world's more successful and effective systems of constitutional review. Each court is routinely asked to determine if and how national law and practice conflicts with treaty-derived law and the answers given to these questions are final. These courts routinely find that some national law and acts are contrary to a state's treaty obligations. Their decisions routinely give guidance to states on how law and practice must change, and states routinely comply with these decisions.

Generally, these perform many of the same functions that most constitutional courts do using similar techniques with broadly similar effects- a fact that deserves much more attention than it has received from scholars. This argument is of the type, "if it looks, walks, and quacks like a duck, then it is probably a duck." In any case, I am going to call it a duck. I emphasize four ways in which the ECJ, ECtHR, and AB appear to behave as constitutional courts.

First, they perform an oracular function, constructing their respective regime's law in a dynamic and progressive way in light of changing circumstances and challenges to the regime's authority. They do so through developing their case law and building precedent.

Second, they adjudicate disputes of a particular structure, one that would be familiar to any national, rights-protecting constitutional court. In each legal system, core treaty values, such as a right or entitlement of an individual or a state, are qualified by other important values, and these qualifications are expressed in the form of derogations that states may claim in the pursuit of some designated public interest. In my view, a court that adjudicates conflicts arising from such a structure is a court inherently operating in a constitutional mode, irrespective of how one understands the constitutional nature of the regime more broadly. Moreover, these decisions tend to impact national law and practices in more or less the same ways as decisions of national constitutional courts.

Third, each of these courts adopted a particular doctrinal framework as a standard technique for dealing with the kinds of disputes just mentioned: propor- 
tionality analysis. Developed as an unwritten, general principle of law by the GFCC, proportionality analysis is a procedure that is widely used by national constitutional judges to adjudicate disputes involving qualified rights. ${ }^{60}$ A highly demanding form of review, proportionality analysis requires the least restrictive means of testing and balancing. It requires courts to supervise the substantive politico-legal decisions of the states they control, and it positions courts to control policy outcomes, thereby reinforcing judicial supremacy. As Jud Mathews and I have shown, ${ }^{61}$ proportionality today is a global constitutional standard that has been adopted by the world's most powerful constitutional and supreme courts.

Fourth, these courts are centrally implicated in the ongoing process of coordinating treaty law with national law in order to make the former more effective within the latter. To my mind, this type of coordination, across otherwise autonomous legal domains, comprises one of the basic functions of constitutional courts. In Europe, the result has been the steady incorporation of the Treaty of Rome and the ECHR into national legal orders. All of the supreme courts of the EU member states eventually chose to accept the doctrines of supremacy and direct effect of EC law through processes that also served to remake national constitutional law. ${ }^{62}$ The ECHR has been integrated into most national legal orders at a rank above statute, and in some cases, it has been given constitutional (even supraconstitutional) status. ${ }^{63}$ The result has been the elimination of traditional dualist orthodoxies across Europe, and the development of a sophisticated pan-European monism, if only in a gradual and piecemeal way. In observing the emergence and evolution of these monist elements, and in tracing their legal effects at both the national and regime level, we build indicators of the constitutionalization of international law, at least within Europe.

Individuals do not have standing in the WTO legal system. Only states may bring a case to WTO panels and appeal panel rulings to the $A B$, and only states are bound by the AB's jurisprudence. It is largely because of this difference that

60. Alec Stone Sweet \& Jud Mathews, Proportionality Balancing and Global Constitutionalism, 47 Colum. J. Transnat'l L. 73, 74-76 (2008).

61. Id. at $112-59$.

62. The "reception" of the ECJ's supremacy doctrine by the national courts has been the subject of intensive research. See Karen Alter, Establishing the Supremacy of European Law: The Making of an International Rule of Law in Europe 16-27 (2001). See generally The European Courts and National Court: Doctrine and Jurisprudence, supra note 46.

63. See Helen Keller \& Alec Stone Sweet, Assessing the Impact of the ECHR on National Legal Systems, in A Europe of Rights: The Impact of the ECHR on National Legal Systems, supra note 55 , at $677,682-88$. 
the WTO has not been incorporated into national legal orders, with the consequent dilution of its impact on those orders. Nonetheless, the constitutional question of the effect of WTO law, and of the AB's case law, will continue to be at the forefront of debates on the evolution of the regime.

\section{Conclusion}

In Part I, I argued that some international regimes display features that make them constitutional in a significant sense. In Part II, I also claimed that the constitutionalization of legal systems is largely the product of how the tensions inherent in legal pluralism are resolved. Finally, in Part III, I presented a case for the view that the courts of the ECHR, the EU, and the WTO are constitutional courts.

Among the many objections to these arguments, I will address three. The first is a purely formal objection: a treaty is not a "constitution" because it is called a treaty, an agreement, or a convention. While labels and rhetoric might make a difference, ${ }^{64}$ this objection can prevail only in the absence of any theoretical attempt to define the concept of a "constitution." Or, one might stipulate that the word "constitution" refers only to the higher law of the Westphalian nation-state, ${ }^{65}$ thus eviscerating the empirical domain and effectively closing down research on the higher law that constitutes legal and political systems more generally.

A second objection focuses attention on the distinction between a "thin" and a "thick" constitution. An international regime only qualifies as a constitutional polity once it develops a thick constitutional identity of its own, and one that does not conflict with basic tenets of democratic theory. ${ }^{66}$ I respond to such an objection with empirical arguments. How would we know when a polity, for instance, a state, has developed a constitutional identity? How many states in world history have developed such a constitutional identity? The answer, I submit, would be only a small minority of states. If one considers the extent of thick constitutional-

64. See Miguel Poiares Maduro, The Importance of Being Called a Constitution: Constitutional Authority and the Authority of Constitutionalism, 3 Int'L J. Const. L. 332, 352 (2005). Maduro focuses on a constitution's role in organizing deliberative processes which is, in turn, linked to the important questions of identifying constituent power and enhancing constitutional legitimacy in the EU. See id. at 350-56.

65. On the various issues that arise with respect to this formulation, see Neil Walker, The EU and the WTO: Constitutionalism in a New Key, in The EU and the WTO: Legal and ConstituTional Issues 31 (Gráinne De Búrca \& Joanne Scott eds., 2001).

66. See id. For a discussion of the various issues that arise with attempts to apply the constitutional law paradigm to non-state entities, see $i d$. at 33-38. 
ism to be a variable across time and polity, then we see that thickness is not a natural state of affairs given in advance, but rather the product of social processes. It also seems obvious that these processes are underway in each of the three regimes considered above. ${ }^{67}$

Finally, a third objection might target my argument about regime courts as constitutional courts. Unlike most other constitutional courts, the courts of the ECHR, the EU, and the WTO do not possess the competence to invalidate national laws that conflict with the regime's law. Each court is regularly asked to determine if and how national law and practice conflicts with treaty-derived law and the answers given to these questions are final. In practice, these courts routinely find that some national laws and acts are contrary to, or in violation of, a state's treaty obligations, and give guidance to states on how their law or practices must change. States routinely comply with these decisions. But, compared to the most powerful national constitutional courts (such as the GFCC) the three regime courts have weaker and less direct means to control if and how the state will comply with its rulings. This point accepted, I see no reason to deny an international court's constitutional status within a treaty regime on the basis of its lack of competence to exercise constitutional authority externally, that is, within national constitutional orders.

My argument can now be simply stated. If most international regimes qualify as constitutional in the sense that they are constituted and governed through meta-norms, some regimes can be considered constitutional in a deeper systemic sense to the extent that they meet three criteria. First, the regime must establish rights, or a bundle of specific legal entitlements among states or other legal persons recognized by the regime that are subject to a judicial mechanism of enforcement. Second, the jurisdiction of the regime's "court" must be compulsory rather than consensual. Third, the members of these courts must employ techniques of adjudication akin to those used by constitutional courts, such as when they resolve conflicts between rights, or state entitlements, on one hand, and those state interests that are recognized by the regime's "constitution" on the other. Because these three elements are present in all three regimes under consideration — the EU, the $\mathrm{ECHR}$, and the WTO — we have every reason to categorize and analyze each as constitutional, and to consider their respective courts-the ECJ, ECtHR, and $\mathrm{AB}$ - as constitutional courts.

67. In the WTO, for example, competition about how to define the nature of the regime provides convincing evidence. 